\title{
TIGA ALASAN BUAH MELON BANYAK DISUKAI ORANG
}

\section{Agustiyah Mardiyanti, Uswatun Khasanah, Tri Lindawati}

Universitas Nahdlatul Ulama Sidoarjo

Email: diyanyanti87@gmail.com

\section{Buah Melon Banyak Disukai Orang}

Ihsan (2018) menjelaskan bahwa melon merupakan jenis tanaman semusim yang merambat tetapi menjalar dan tidak memanjat. Daun melon berbentuk menjari dan bunganya memiliki dua tipe, bunga jantan dan hermaprodit. Buah melon berbentuk bulat. Melon mempunyai nama ilmiah cucu mismelo. Menurut saya, melon merupakan salah satu buahyang banyak disukai orang, karena melon memiliki rasa yang enak, buahnya manis dan segar. Tidak hanya rasanya saja yang enak, melon juga banyak mengandung vitamin dan nutrisi yang baik untuk kesehatan tubuh.

Buah melon memiliki bentuk bulat alami, melon termasuk buah - buahan yang banyak disukai banyak orang. Bentuk bulat dari buah melon bukanlah bentuk yang paling efisien dalam urusan logistic, karena buah melon sulit ditumpuk, dengan bentuknya yang 
bulat, buah melon dapat menggelinding dan memiliki sisa ruang/celah antara buah. Oleh karena itu buah semangka atau melon kotak kini bukanlah bentuk yang asing lagi bagi masyarakat.(Purnomo \& Rosyidah, 2010).

Buah melon biasanya disajikan dirumah sebagai pencuci mulut, buah ini juga bisa dijadikan sebagai campuran minuman seperti es buah, manisan buah dan juga untuk rujak manis. Kisaran harga buah melon biasanya 10 ribu rupiah per $\mathrm{Kg}$. Buah melon sering ditemui di daerah persawahan atau pegunungan, dan mudah diperoleh dari pedagang kaki lima atau ditoko buah karena disetiap toko buah pasti ada buah melon.

(Tohir, 2018), buah melon masuk ke Indonesia dan mulai dibudidayakan pada tahun 1970 daerah pertama yang mengembangbiakan melon yaitu Kalianda (Lampung) dan Cisarua (Bogor) yang selanjutnya daerah Ngawi (Jawa Timur), serta Boyolali dan Klaten (Jawa Tengah) yang menjadi sentra melon yang cukup dominan. Maghfoer, Wardiyati, \& Purnomo (2007) menjelaskan bahwa buah Melon dapat diproduksi dengan hidroponik rakit apung.

Ihsan(2018), melon merupakan salah satu jenis buah yang termasuk dalam suku labu-labuan (Cucurbitacea). Pendapat saya, pada umumnya buah melon berbentuk bulat 
dan termasuk dari keluarga labulabuanseperti blewah, semangka dan lain sebagainnya. Melon merupakan tumbuhan yang berbiji tertutup karena bijinya yang ditutupisama bakal buahnya. Buah melon kebanyakan berwarna hijau, kulit luarnya juga sangat keras, kasar dan memiliki urat seperti jala. Daging buahnya memiliki warna hijau pucat dan juga aromanya yang harum membuat orang ingin memakannya terus menerus. Sholichah et al. (2018) memaparkan bahwa semua yang dibutuhkan oleh umat manusia telah disediakan oleh Allah SWT termasuk buah.

Adam(2011), jenis - jenis melon yang terkenaladalah melon Christianism(1850), melon Sill Hybrid (1870), melon Surprise (1876), melon Ivondequoit, Miller Cream, Netted Gem, Hacken Sack, Osage (18811890), melon Honey Rock, Improved Perfecto (1933), melon Imperial (1935), melon Queen of Colorado dan Honey Gold (1939). Untuk memudahkan sistem penanaman dan pengelompokan melon, para ahli mengklasifikasikan melon dalam dua tipe, yaitu:

1) Tipe Netted-Melon

1. Ciri-ciri: kulit buah keras, kasar, berurat dan bergambar seperti jala (net), aroma relative lebih harum disbanding dengan 
winter-melon lebih cepat masak antara 75-90 hari, awet dan tahan lama untuk disimpan.

1. Varietas: Cucumismelo var. reticulatus, buah kecil, berurat seperti jala dan harum

2. Cucumismelo var. cantelupensis, buah besar, kulit bersisik dan harum.

2) Tipe Winter-Melon

1. Ciri-ciri: kulit buah halus, mengkilat, aroma buah tidak harum, buah lambat untuk masak antara 90-120 hari, mudah rusak dan tidak tahan lama untuk disimpan dan tipe melon ini sering digunakan sebagai tanaman hias.

2. Varietas:

1. Cucumismelo var. inodorous, kulit buah halus, buah memanjang dengan diameter 2,5-7,5 cm

2. Cucumismelo var. flexuosus, permukaan buah halus, buah memanjang antar 35-70 cm

3. Cucumismelo var. dudain, ukuran kecil-kecil, sering untuk tanaman hias

4. Cucumismelo var. chito, ukuran buah sebesar jeruk lemon, sering digunakan sebagai tanaman hias.

Buah melon dimanfaatkan sebagai makanan buah segar dengan kandungan vitamin $\mathrm{C}$ yang cukup tinggi. 


\section{Kesimpulan}

Bahwa buah melon banyak diminati oleh masyarakat Indonesia karena rasanya yang enak,buahnya yang manis dan segar bisa sebagai hidangan penutup (desert) atau jus sebagai pelepas dahaga dan bahkan dijadikan bahan baku industri minuman. Buah melon adalah buah yang banyak mengandung air, selain rasanya yang enak buah ini juga mengandung banyakvitamin dan nutrisi yang berguna untuk kesehatan tubuh kitaharganya juga terjangkau.

\section{References}

Adam. (2011). tanaman buah melon.

Retrieved April 20, 2018, from

https://buahku.wordpress.com/2011/07/24

/tanaman-buah-melon/

Ihsan. (2018). Klasifikasi Tanaman melon.

Retrieved April 20, 2018, from

https://www.petanihebat.com/klasifikasi-

tanaman-melon/

Maghfoer, M. D., Wardiyati, T., \& Purnomo, A.

(2007). Pengaturan Jarak Panel dengan

Permukaan Media pada Teknik

Hidroponik Sistem Terapung Tanaman

Melon. Agrivita, 9 (Khusus), 388-396. 
Purnomo, A., \& Rosyidah, E. (2010). Rumah Kotak Tumbuh bagi Keluarga Semangka.

In 102 Inovasi Indonesia. Jakarta:

Business Innovation Center.

Sholichah, S. A., Asitah, N., Maula, I.,

Munjidah, A., Nahdiyah, K., Yuniarti, D.,

Purnomo, A., Rosyidah, Elsa., Achmadi,

A. K., Oktawila, Denok, . Anam, F. (2018,

May 25). Aksentuasi Islam Berintelektual

dan Bersifat Universal.

http://doi.org/10.17605/OSF.IO/DXJEA

Tohir. (2018). Mengenal Tanaman Melon,

Klasifikasi dan Morfologinya. Retrieved

April 20, 2018, from

http://chyrun.com/mengenal-tanaman-

melon-klasifikasi-dan-morfologinya/ 